\title{
EFEKTIVITAS PENGGUNAAN MODUL TERHADAP PENINGKATAN NILAI AKHIR SISWA PADA PELAJARAN BAHASA INGGRIS
}

\author{
Tutut Wahayuningrum \\ tututwahayu@gmail.com
}

\begin{abstract}
Abstrak
Modul sebagai sarana media pembelajaran dapat menjadi salah satu salusi dalam menerapkan model pembelajaran SAINTIFIK yaitu dengan menggunakan prinsipprinsip pembelajaran berbasis pada siswa (selft concept) yang artinya adalah pembelajaran yang dilakukan dengan orientasi pencapaian kompetensi peserta didik, sehingga tujuan akhir hasil pembelajaran adalah meningkatkan kompetensi peserta didik yang dapat diukur dalam pola sikap, pengetahuan, dan keterampilannya.

Berangkat dari konsep tersebut, studi ini ditujukan untuk mengkaji secara empiris efektifitas modul dalam meningkatkan kemampuan bahasa Inggris siswa yang diukur melalui nilai akhir siswa yang dilakukan dengan menggunakan pendekatan independent sample $t$ test.

Hasil pengujian empiris yang dilakukan pada studi ini menunjukkan bahwa pemberian modul kepada siswa terbukti efektif untuk meningkatkan kemampuan bahasa Inggris siswa yang ditunjukkan dari perolehan nilai akhir siswa.
\end{abstract}

\section{Kata Kunci: modul, efektifitas}

\section{PENDAHULUAN}

Guru merupakan pilar utama dalam memajukan dunia pendidikan. Melalui guru, pembelajaran pelbagai ilmu pengetahuan, keterampilan, dan pengalaman yang relevan dengan perkembangan teknologi dapat berlangsung, serta penanaman nilai-nilai budi pekerti dan budaya bangsa dapat ditanamkan oleh guru.Dengan demikian guru sebagai sentral dalam kemajuan dunia pendidikan. Seiring dengan perubahan paradikma pendidikan sekarang ini yang menuntut seorang guru tidak hanya memiliki kompetensi dalam menguasai pengetahuan dalam penyampaian pembelajaran saja melainkan juga harus mampu merancang dan melaksanakan proses secara aktif, inovatif, kreatif, efektif, dan menyenangkan atau yang dikenal dengan model pembelajaran SAINTIFIK. Dengan kegiatan pembelajaran yang 
demikian diharapkan guru dapat membantu siswa mengembangkan kompetensi berfikir tahap tinggi, berfikir, berfikir kritis dan berfikir kreatif (critical and creative thingking).

Namun dalam kegiatan sehari-hari masih banyak guru-guru dalam proses pembelajaran hanya sebagai penyaji materi pelajaran, sehingga kegiatan pembelajaran hanya sebagai sarana untuk transfer of knowlegde, untuk pembentukan kepribadian dan penanaman nilai-nilai budi pekerti terabaikan.

Berdasarkan hasil supervisi kunjungan kelas yang dilaksanakan pengawas, sebagian besar guru di Kota Semarang masih menggunakan pendekatan pembelajaran secara konvensional. Mereka kurang kreativ dalam mengembangkan metode mengajar dan minim sekali dalam menggunakan media pembelejaran sehingga kegiatan belajar mengajar berlangsung secara monoton dan menjenuhkan serta komunikasipun lebih banyak terjadi satu arah, sehingga keaktifan siswa masih kurang.

Salah satu upaya yang dapat dilakukan untuk meningkatkan kualitas proses pembelajaran adalah adanya pembinaan terprogram yang dilakukan oleh pengawas sekolah. Pengawas Sekolah Menengah merupakan unsur tenaga kependidikan yang memiliki peran penting dalam mendorong guru untuk melakukan proses pembelajaran yang menuju pada perubahan dan peningkatan mata pendidikan formal .

Terdapat beberapa faktor yang menjadi penyebab masih rendahnya penerapan pembelajaran SAINTIFIK bagi guru bahasa Inggris : (1) Belum semua guru mempu memaksimalkan media pembelajaran dalam yang dapat membuat siswa aktif dan sekaligus menyenangkan; (2) Sebagian besar guru dalam proses pembelajaran menggunakan metode ceramah dengan variasi tanya jawab; (3) Kurangnya pengetahuan dan wawasan para guru dalam melaksanakan proses pembelajaran dengan metode Saintifik.

Atas dasar kondisi yang demikian maka peneliti terdorong untuk melakukan penelitian tentang perlunya Penggunaan Modul sebagai salah satu sarana media pembelajaran guru untuk meningkatan nilai akhir siswa pada pelajaran bahasa Inggris. 


\section{Tujuan}

1. Tujuan umum

Meningkatkan kompetensi siswa dan guru dalam penerapan pembelajaran dengan memaksimalkan media pembelajaran dalam system pemelajaran Saintifik di SMK Negeri 3 Semarang.

2. Tujuan khusus

Meningkatkan kompetensi siswa dan menaikkan nilai akhir dengan pengunaan modul sebagai sarana media pembelajaran pembelajaran untuk mata pelajaran Bahasa Inggris bagi siswa SMK Negeri 3 Semarang pada semester gasal Tahun Pelajaran 2016/2017

\section{LANDASAN TEORI DAN HIPOTESIS TINDAKAN}

\section{Kompetensi Guru}

Kompetensi berasal dari bahasa Inggris competency yang berarti kecakapan, kemampuan, dan wewenang. Seseorang dikatakan kompeten di bidang tertentu jika menguasai kecakapan bekerja pada suatu bidang tertentu.

Dalam Permendiknas Nomor 23 Tahun 2006 tentang Standar Kompetensi Lulusan, bahwa kompetensi adalah kemampuan berfikir, bersikap dan bertindak secara konsisten sebagai perwujudan dari pengetahuan, sikap, dan keterampilan yang dimiliki peserta didik (seseorang). Sedangkan menurut Depdiknas (2001: 51) kompetensi guru adalah kemampuan melakukan tugas mengajar dan mendidik yang diperoleh melalui pendidikan dan latihan.

Berdasarkan pendapat para ahli tersebut, maka dapat disimpulkan bahwa kompetensi guru adalah kemampuan seseorang dalam melaksanakan tugas pokok dan fungsinya sesuai kemampuan yang dimilikinya secara bertanggungjawab.

\section{Media Pembelajaran}

Sejalan dengan paradigma pendidikan dewasa ini, kurikulum menuntut seorang guru untuk tidak saja memiliki kompetensi menguasai pengetahuan di 
bidangnya melainkan juga mampu merancang dan melaksanakan proses pembelajaran yang aktif, inovatif, kreatif, efektif dan menyenangkan.

Berbagai jenis dan macam sumber dan bahan ajar dapat digunakan dalam pembelajaran. Salah satu bentuk sumber belajar dan bahan ajar yaitu cetakan seperti buku, modul, ensiklopedia, dan bentuk cetakan lainnya. Modul sebagai salah satu bahan ajar berbentuk cetak sangat baik digunakan dalam pembelajaran. Diknas menjelaskan dalam buku Pedoman Umum Pemilihan dan Pemanfaatan Bahan Ajar (2004) bahwa modul adalah sebuah buku yang ditulis dengan tujuan agar peserta didik dapat belajar secara mandiri tanpa arahan atau bimbingan guru. Ini menunjukkan bahwa modul dapat digunakan untuk pembelajaran meskipun tidak ada pengajaran.

Modul yang dihasilkan agar mampu meningkatkan motivasi penggunanya, maka modul harus mencakup beberapa karakteristik tertentu. Karakteristik untuk pengembangan modul berdasarkan Depdiknas (2008:3) antara lain :

1. Self Instructional, yaitu melalui modul tersebut seseorang atau peserta belajar mampu membelajarkan diri sendiri, tidak tergantung pada pihak lain. Untuk memenuhi karakter self instructional, maka dalam modul harus;

1) berisi tujuan yang dirumuskan dengan jelas

2) berisi materi pembelajaran yang dikemas ke dalam unit-unit kecil/spesifik sehingga memudahkan belajar secara tuntas;

3) menyediakan contoh dan ilustrasi yang mendukung kejelasan pema- paran materi pembelajaran;

4) menampilkan soal-soal latihan, tugas dan sejenisnya yang memungkinkan pengguna memberikan respon dan mengukur tingkat penguasaannya;

5) kontekstual yaitu materi-materi yang disajikan terkait dengan suasana atau konteks tugas dan lingkungan penggunanya;

6) menggunakan bahasa yang sederhana dan komunikatif

7) terdapat rangkuman materi pembelajaran;

8) terdapat instrumen penilaian yang memungkinkan pengguna modul melakukan 'self assessment'; 
9) terdapat instrumen yang dapat digunakan penggunanya mengukur atau mengevaluasi tingkat penguasaan materi;

10) terdapat umpan balik atas penilaian, sehingga penggunanya mengetahui tingkat penguasaan materi; dan

11) tersedia informasi tentang rujukan/pengayaan/referensi yang mendukung materi pembelajaran dimaksud.

2. Self Contained, yaitu seluruh materi pembelajaran dari satu unit kompetensi atau sub kompetensi yang dipelajari terdapat di dalam satu modul secara utuh. Tujuan dari konsep ini adalah memberikan kesempatan pembelajar mempelajari materi pembelajaran yang tuntas, karena materi dikemas ke dalam satu kesatuan yang utuh. Jika harus dilakukan pembagian atau pemisahan materi dari satu unit kompetensi harus dilakukan dengan hati-hati dan memperhatikan keluasan kompetensi yang harus dikuasai.

3. Stand Alone (berdiri sendiri), yaitu modul yang dikembangkan tidak tergantung pada media lain atau tidak harus digunakan bersama-sama dengan media pembelajaran lain. Dengan menggunakan modul, pebelajar tidak tergantung dan harus menggunakan media yang lain untuk mempelajari dan atau mengerjakan tugas pada modul tersebut. Jika masih menggunakan dan bergantung pada media lain selain modul yang digunakan, maka media tersebut tidak dikategorikan sebagai media yang berdiri sendiri.

4. Adaptive, modul hendaknya memiliki daya adaptif yang tinggi terhadap perkembangan ilmu dan teknologi. Dikatakan adaptif jika modul dapat menyesuaikan perkembangan ilmu pengetahuan dan teknologi, serta fleksibel digunakan. Dengan memperhatikan percepatan perkembangan ilmu dan teknologi pengembangan modul multimedia hendaknya tetap "up to date". Modul yang adaptif adalah jika isi materi pembelajaran dapat digunakan sampai dengan kurun waktu tertentu.

5. User Friendly, modul hendaknya bersahabat dengan pemakainya. Setiap instruksi dan paparan informasi yang tampil bersifat membantu dan bersahabat dengan pemakainya, termasuk kemudahan pemakai dalam merespon, mengakses sesuai dengan keinginan. Penggunaan bahasa yang sederhana, 
mudah dimengerti serta menggunakan istilah yang umum digunakan merupakan salah satu bentuk user friendly.

\section{Hipotesis Tindakan}

Berdasarkan kajian teori dan kerangka berpikir diajukan hipotesis tindakan sebagai berikut "Melalui sarana modul sebagai media pembelajaran dapat meningkatkan kompetensi siswa dan menaikkan nilai akhir pada mata pelajaran Bahasa Inggris di SMK Negeri 3 pada semester gasal Tahun Pelajaran 2016/2017”.

\section{METODA PENELITIAN}

\section{Desain Penelitian}

Penelitian ini menggunakan metoda eksperimen lapangan (field experiment) yang menginvestigasi secara empiris dampak pemberian modul terhadap kompetensi penguasaan bahasa inggris yang ditunjukkan dari perubahan nilai siswa secara individual. Pemilihan metoda penelitian eksperimen dilakukan dalam upaya menguji hubungan kausalitas antara variabel independen dengan variabel dependen. Metoda eksperimen memiliki keunggulan yaitu kemampuannya menjawab pertanyaan tentang hubungan kausalitas antarvariabel penelitian. Desain penelitian dengan tidak menginformasikan kegiatan eksperimen kepada subjek dalam penelitian ini termasuk dalam single-blind experiment, yaitu menggunakan eksperimenter yang mengetahui tujuan penelitian namun subjek tidak mengetahui kegiatan eksperimen (Neuman, 2010).

Penelitian ini juga termasuk dalam eksperimen lapangan (field experiment). Dalam pengujian dengan eksperimen lapangan, manipulasi dan kontrol diberikan dalam kegiatan pekerjaan subjek dalam durasi waktu tertentu (Sekaran dan Bougie 2010). Pengujian hipotesis diklasifikasikan dalam pretest-posttest group design. (Shadish, Cook dan Campbell 2002). 


\section{Subjek Eksperimen}

Partisipan dalam eksperimen terdiri dari siswa kelas kelas XA dan XB tahun ajaran 2016/2017. Partisipan diklasifikasikan dalam dua kondisi manipulasi yaitu diberikan modul dan tidak diberikan modul bahasa inggris.

\section{Teknik Analisis Data}

Mengacu pada hasil uji normalitas data maka terdapat dua pendekatan uji statistik yang digunakan untuk menguji hipotesis komparatif, yaitu:

Uji independen Sample t Test dilakukan untuk menguji apakah terdapat perbedaan antara nilai akhir pada mata pelajaran Bahasa Inggris di SMK Negeri 3 pada semester gasal Tahun Pelajaran 2016/2017”.

\section{HASIL PENELITIAN}

Bagian ini merupakan pengujian statistik yang dilakukan untuk mengetahui apakah secara empiris terdapat perbedaan nyata antara kompetensi penguasaan bahasa inggri pada kelas yang diberi modul dan yang tidak diberi modul. Uji beda pada nilai akhir pada mata pelajaran Bahasa Inggris di SMK Negeri 3 pada semester gasal Tahun Pelajaran 2016/2017.

\section{Uji Asumsi Normalitas}

Uji asumsi normalitas dilakukan untuk mengetahui apakah data penelitian memiliki sebaran normal atau memenuhi asumsi normalitas. Pengujian normalitas data dilakukan dengan menggunakan Uji Kolmogorov Smirnov dengan kriteria sebagai berikut:

a. Jika signifikansi $>0,05$ maka data berdistribusi normal

b. Jika signifikansi $<0,05$ maka data tidak berdistribusi normal

Hasil uji Kolmogorov Smirnov pada data nilai akhir siswa yang diberi modul dan nilai akhir siswa yang tidak diberi modul menghasilkan nilai signifikansi sebesar 0,869. Nilai signifikansi sebesar 0,869 tersebut lebih besar dari 0,05 sehingga dapat disimpulkan bahwa data penelitian memenuhi asumsi normalitas. 


\section{Hasil Uji Beda pada Pemberian Modul dan Tidak Diberi Modul}

Berpijak pada hasil pengujian normalitas data dapat diketahui bahwa data penelitian memiliki distribusi normal sehingga untuk menguji ada atau tidaknya perbedaan antara data nilai akhir kelompok siswa yang diberi modul dan tidak diberi modul dilakukan dengan menggunakan Uji Independent Sample t Test. Pengujian dilakukan dengan tahapan berikut ini:

a. Pengujian asumsi homogenitas variance

Pengujian asumsi homogenitas variance dilakukan dengan menganalisis nilai signifikansi Levene's Test for Equality of Variance dengan kriteria sebagai berikut:

1) Jika nilai signifikansi $>0,05$ artinya variance data adalah homogen

2) Jika nilai signifikansi $<0,05$ artinya variance data adalah tidak homogen

Hasil signifikansi nilai Levene's Test for Equality of Variance adalah sebesar 0,303 sehingga dapat disimpulkan bahwa data memiliki variance yang homogen.

b. Pengujian perbedaan

Merujuk pada hasil signifikansi Levene's Test for Equality of Variance maka untuk menguji ada atau tidaknya perbedaan kelompok siswa yang diberi modul dan kelompok siswa yang tidak diberi modul dilakukan dengan menganalisis nilai signifikansi pada output Equal Variance Assumed dengan kriteria sebagai berikut:

a) Jika signifikansi $<0,05$ artinya terdapat perbedaan yang signifikan

b) Jika signifikansi $>0,05$ artinya terdapat perbedaan yang signifikan

Hasil pengujian komparatif dengan Uji Independent Sample t Test menghasilkan nilai signifikansi sebesar 0,000 dimana nilai signifikansi tersebut lebih kecil dari 0,05. Dengan demikian dapat disimpulkan bahwa hipotesis alternatif yang menyatakan yaitu "sarana modul sebagai media 
pembelajaran dapat meningkatkan kompetensi siswa dan menaikkan nilai akhir pada mata pelajaran Bahasa Inggris di SMK Negeri 3 pada semester gasal Tahun Pelajaran 2016/2017" dapat diterima dan dibuktikan kebenarannya secara statistik.

Pada analisis deskriptif diperoleh rerata nilai akhir untuk kelompok siswa yang diberi modul sebesar 76,18 dan rerata nilai akhir kelompok siswa yang tidak diberi modul sebesar 63,98. Artinya, pemberian modul bahasa inggris kepada siswa efektif untuk meningkatkan nilai akhir siswa.

\section{PENUTUP}

\section{Kesimpulan}

Kajian empiris yang telah dilakukan pada studi ini melalui pemberian perlakukan modul pada kelompok siswa kelas XA dan XB tahun ajaran 2016/2017 telah membuktikan bahwa rerata nilai akhir pada kelompok siswa yang diberi modul lebih tinggi jika dibandingkan dengan rerata nilai akhir kelompok siswa yang tidak diberi modul. Temuan ini menjadi bukti bahwa pemberian modul pembelajaran sebelum kegiatan pembelajaran dimulai secara efektif dapat meningkatkan nilai akhir siswa.

\section{Saran}

Merujuk pada hasil penelitian ini maka implikasi manajerial yang diarahkan adalah agar guru dapat mempersiapkan modul pembelajaran sesuai masing-masing pelajaran yang diampu untuk diberikan kepada siswa sebelum kegiatan pembelajaran dimulai.

\section{DAFTAR PUSTAKA}

Permendiknas Nomor 23 Tahun 2006 tentang Standar Kompetensi Lulusan Depdiknas (2008), Kurikulum Tingkat Satuan Pendidikan, Dikmenum, Jakarta Pedoman Umum Pemilihan dan Pemanfaatan Bahan Ajar (2004) 